\title{
POST-COLD WAR MILITARY INTERVENTION IN AFRICA
}

\section{Capt Mashudu Godfrey Ramuhala \\ Faculty of Military Science, Stellenbosch University}

\begin{abstract}
Military intervention remains controversial both when it happens and when it fails to happen. Since the end of the Cold War, military intervention has attracted much scholarly interest, and it was demonstrated that several instances of the use of force or the threat to use force without Security Council endorsement were acceptable and necessary. Matters of national sovereignty remain the fundamental principle on which the international order was founded since the Treaty of Westphalia. Territorial integrity of states and non-interference in their domestic affair, continue to be the foundation of international law, codified by the United Nations Charter, and one of the international community's decisive factors in choosing between intervention and non-intervention. Nevertheless, since the end of the Cold War, matters of sovereignty and non-interference have been challenged by the emergent human rights discourse amidst genocide and war crimes. The aim of this article is to explain the extent to which military intervention in Africa has evolved since the end of the Cold War in terms of theory, practice and the way military intervention unfolded upon the African continent. This will be achieved by focusing on both successful and unsuccessful cases of military intervention in Africa. The unsuccessful cases include Somalia in 1992, Rwanda in 1994 and Darfur in 2003 on the one hand, and the successful cases being Sierra Leone in 2000 and the Comoros in 2008 on the other. While the unsuccessful cases attracted much scholarly attention and controversy, given their prolonged nature and difficulty in terms of conclusion, successful cases were short in terms of time and attracted little scholarly attention and controversy.
\end{abstract}

\section{Introduction}

Military intervention remains a contentious matter, and Africa is no

Scientia Militaria, South African Journal of Military Studies, Vol 39, Nr 1, 2011, pp. 33-55. doi: $10.5787 / 39-1-101$ exception. The contention centres around three questions: firstly, who should intervene in the affairs of a sovereign state? Secondly, on which grounds should an intervention be 
based? Thirdly, how applicable is the principle of non-interference in the age of globalisation where matters of sovereignty seem to have taken a backseat and been replaced by human rights?

Notwithstanding previous attempts to tone down the sovereign powers of states through non-intervention norms and the Just War Theory, intervention remains a challenge. The humanitarian argument or the legal arguments of international law also seem to have failed to break the controversy continuum. ${ }^{1}$ With Africa being at the centre of post-Cold War military interventions, the continent is thus not immune to intervention dilemmas - despite the paradoxical need for intervention. In order to achieve peace and stability, there is a seemingly perceived need for intervention. It can also be pointed out that the prevalence of conflicts in Africa eventually require, or could require, a military response, and states as well as regional and global institutions such as the African Union (AU) and the United Nations (UN) all cater for this scenario. Such an eventuality does have a negative reputation in the sense that it has to manoeuvre around complex issues of sovereignty. However, in Africa, the armed conflicts in several cases, seem to require a harsh response.

In view of the previously mentioned, it is worth noting that this article seeks to focus primarily on military intervention, but it acknowledges that issues such as human rights and morality have become fixtures in the interventionist debate. The $\mathrm{AU}$, for example, claims the right to intervene in member states under certain conditions. As a result, the debate around sovereignty with regard to when to intervene is legitimate; however, debate as to who should intervene remains a polemic question. In studying military intervention, certain choices need to be made, given that this phenomenon remains a challenge in the international community in general and in Africa in particular. Based on these observations, the problematic nature of intervention consequently remains salient in the interventionist debate and calls for persistent scholarly attention.

The uncertainty of future interventions as a result of the unceremonious departure of the US forces from Somalia, has arguably led to lethargy in terms of the need for intervention as in Rwanda. Similarly, the international community has been involved in the semantics of delineating the events in Darfur as genocide rather than designing an intervention strategy that seeks to address an ostensibly catastrophic humanitarian disaster. However, the interventions in Sierra Leone and the Comoros provide some optimism on how both regional entities, such as the AU, and Western powers should go about intervening for future reference.

The cases under discussion include the 1992 United States (US)-led intervention in Somalia, the 1994 intervention in Rwanda, the intervention in Darfur 
in 2004, the 2000 intervention by Britain in Sierra Leone, and the 2008 African Union (AU) intervention in the Comoros. The criteria for these interventions hinge upon the unsuccessful ones as well as successful ones. Somalia, Rwanda and Darfur are epitomes of unsuccessful cases of intervention, given that in Rwanda intervention never happened, or happened much too late after the death of almost a million people, while Somalia is an extreme case of an ongoing conflict amidst numerous military interventions and an almost totally collapsed state. Darfur, on the other hand, represents a case that followed Rwanda, where in the latter case pronouncements were made to avoid a repeat of the former. Sierra Leone and the Comoros illustrate successful cases of intervention. In Sierra Leone a state (Britain), with the capacity to carry out such an intervention, was willing and able to stage an intervention, while the Comoros represents a more contemporary case where the AU intervened successfully.

Since the end of the Cold War, the most contentious revolution in United Nations (UN) activities has been the amplified resort to peace enforcement, i.e. armed intervention, or the threat of armed intervention, pursuant of a UN mandate authorising the coercive use of military power to induce conformity with UN sanctions or resolutions. While the UN launched only one enforcement operation between 1945 and 1990 - in Korea in 1950 - four have been authorised since then: Kuwait (1990), Somalia (1992), Rwanda (1994) and Haiti (1994), and two others have been supported: Liberia (1990) and Northern Iraq (1991). The emergence of this new practice of $\mathrm{UN}$-sponsored military intervention has generated debate among academia and among political elites concerning the legitimate use of force, the arguments for and against a UN standing army, and the conditions for success. Less attention has been directed to the question of why a variety of military interventions was initiated. ${ }^{2}$

\section{The Case of Somalia, 1992}

Due to its geographic location, Somalia drew super-power attention for much of the Cold War period. By March 1991, after the demise of the Cold War, Somalia again emerged central to post-Cold War interventions. One and a half years before the 1992 intervention, Assistant Secretary of State, Herman Cohen pronounced Somalia a civil strife disaster, at which point the United States Office of Foreign Disaster Assistance began to fund relief efforts. Nonetheless, it was not until the spring of 1992 that Somalia became a major issue in Washington. An admixture of strenuous lobbying by officials within the US executive coupled with increased media attention raised the profile of Somalia during this period. By 14 August 1991, the Bush administration had ordered a major airlift of relief supplies - Operation Provide Relief to Somalia. The airlift represented a major intensification in US 
involvement with the Somalia crisis. It epitomised George Bush's political commitment to that country. ${ }^{3}$

Talentino argues that emergency aid became the only currency of an already collapsed economy, thus indicative of a method of acquiring both money and power. As aid poured in, it provided both prospects and competition for resources, and this led to two problems. Firstly, the availability of aid amplified violence as gangs and factions competed for control of international supplies. Secondly, the focus on Mogadishu as a distribution point brought the displaced population into the areas of intense conflict, thus subjecting more desperate people to the warlords. With the situation exacerbating on a daily basis, the distribution of aid became intricate and impossible, threatening the humanitarian operation in its entirety. ${ }^{4}$

After a series of interagency meetings, which were called in a bid to develop policy options for President Bush, three options had been developed. The first was continuing with aid operations and seeking to enhance the UN presence in Somalia. The second involved organising an international coalition of forces under UN command in which US military airlift, sealift and logistical and communications support would be offered but not ground troops. The third option was sending in a division of US troops under US command and control. ${ }^{5}$ On 25 November 1991, Bush agreed on the third option and proceeded to offer the UN up to 28000 troops to spearhead an intervention. It was on 4 December that the UN Security Council voted to support intervention, and an announcement was made by Bush that US troops would be sent to Somalia. By 9 December, the first US troops were arriving in Somalia. ${ }^{6}$ These troops were subsequently joined by other forces to create a United Task Force (UNITAF), which was charged with restoring security in limited geographic areas to allow the distribution of aid. ${ }^{7}$ The story from this point on is the now infamous departure of US troops but, of significance in this article, is the rationale behind the intervention. Why did the international community choose to respond in Somalia in the manner that it did?

\section{International response to the crisis in Somalia}

Bolton avers that, by the end of the 1991 Persian Gulf War, pressure mounted to involve the $\mathrm{UN}$ in a burgeoning number of countries experiencing internal civil strife, and Somalia is a paradigm case. What President Bush originally decided, and the Clinton administration later did, reflects a disjuncture in terms of approaches. It is evident that the Bush administration sent US troops into Somalia strictly to clear relief conduits that could forestall mass starvation and resist UN attempts in expanding the mission. The Clinton administration set about pioneering 
"assertive multilateralism" and efforts at nation building that led to the violence and humiliation that ensued. ${ }^{8}$

It is further argued that, as a UN imperative, legitimating its involvement in internal civil strife evolved as an extension of the duty to preserve international security. The turning point came in the aftermath of the Persian Gulf War, when the UN Security Council adopted Resolution 688 in 1991. Having to contend with immense flows of Kurdish refugees from northern Iraq into Turkey and Iran, as well as callous military assaults against Shiites in southern Iraq, the council acted summarily. It was then declared, for the first time, that a member government's repression of its own people, resulting in urgent humanitarian needs, constituted a threat to international peace and security. ${ }^{9}$

When the Somalian crisis came, the Security Council achieved little progress in early and mid-1992, brokering a ceasefire among the warring clans and sub-clans. General Mohamed Farah Aideed rejected the deployment of peacekeepers until autumn. By not deploying the UN Operation in Somalia (UNOSOM), the SecretaryGeneral followed standard peacekeeping procedures: no 'blue helmets' would be deployed unless all parties consented. The result was that the civil war in Somalia continued unabated, humanitarian assistance could not be delivered, thousands of Somalis died of disease and starvation, and the threat to hundreds of thousands more grew daily. ${ }^{10}$

It is worth noting that the conflict in Somalia had been ongoing for several years by the time military intervention began in 1992. This, of course, is indicative of the fact that it was not so much the presence of violence that prompted action, but something else. Instead of seizing the moment created by instability, the international actors tried not to get involved and virtually ignored the political crisis. The initial efforts were, to a large extent, driven by the humanitarian agenda, and the notion that the crisis might have security upshots was voiced in UN debate in early 1992. This was not broadly accepted. ${ }^{11}$ These circumstances marked an important milestone for intervention and not only in Somalia but also in post-Cold War international relations. They brought about change in the perceived uses of intervention by producing a humanitarian raison d'être for military actions. It is clear that nations do not employ their militaries to do good for others, and intervention in a sovereign state is usually considered amiss. Without doubt, Somalia presented a case where the scope of the tragedy induced by both humans and nature created pressure on observers to act in unusual ways on behalf of perceived humanitarian interests. $^{12}$

It also appears as though the normative fervour to provide humanitarian relief was based on the premise that doing so would be easy and less costly. In a 
way, this case does correspond to explanations of why states intervene, and does not suggest a complete departure from the rule of self-interests. Significant though, the US did not construe UNITAF as aiding itself or Somalia, only Somalis. The distinction is delicate here, yet significant. Therefore, for all parties involved, the humanitarian crisis - not the political crisis - justified intervention. ${ }^{13}$ Intervening in Somalia was important for another reason, but US policy-makers felt that they faced a choice between joining an intervention in Bosnia and leading an effort in Somalia. Notwithstanding the fact that intervention in Somalia would not yield any benefits, the US certainly preferred its problems and terrain to the violence in Bosnia. For the US, acting in Somalia helped in sparing them from international pressure to act in Bosnia; thus proving the humanitarian bona fides, but in a slightly less costly manner. $^{14}$

In addition, the increased level of agreement within the Security Council because of the end of the Cold War meant that, for the first time, military action could be linked to and thus restrained by UN consensus. In this case, Boutros-Ghali endorsed the use of the military to distribute relief supplies and conceived of intervention as part of a larger programme of conflict resolution. It is evident that his arguments were augmented by the fact that Somalia involved two issues with normative connotations: sovereignty and human rights. It is also clear that Security Council debates relied on the conviction that complete anarchy justified force, because it created 'a unique situation' that demanded an equally unique solution. By judging the humanitarian and political crisis as a threat to international peace and security, the Security Council could invoke the right of enforcement, but did not consider this argument to establish a rationale for action outside Somalia. Consequently, it can be argued that this case was not intended to set up broad legitimacy for military interference and the arguments were limited to Somalia. Such a stance was espoused short of any endeavour to engage broader issues, by making internal violence or its consequence components of international agenda. The uniqueness of this case, they hoped, should not set precedence and should not shape expectations in the future. ${ }^{15}$ Whilst Somalia remains a bitter pill to swallow within US and international community circles, Rwanda became a tale of missed opportunities and lethargy for the international community at large.

\section{The Case of Rwanda, 1994}

Subsequent to the death of Rwandan President Habyarimana on 6 April 1994, the Hutu-dominated Presidential Guard began their systematically killing of critics of the regime and members of the Tutsi minority. The UN reacted by inconceivably reducing its presence from 2500 to 270. Apprehensions of another 
Somalia initially deterred the Western powers from acting and one million people had to die before France finally offered to undertake a 'humanitarian intervention' in mid-June 1994. The Security Council accepted the offer and French troops entered Rwanda to set up a humanitarian protection zone in the border area. The French force handed over the operation to the United Nations Assistance Missions for Rwanda (UNAMIR) on 21 August $1994 .^{16}$

\section{International response to the Rwandan genocide}

Since the story of the Rwandan genocide has been recounted in numerous studies, as well as academic and journalistic accounts, ${ }^{17}$ this section will not recount that story in detail. Instead, it seeks to outline the politics behind intervention. As early as April 1994, non-governmental organisations (NGOs), the press and the commander of the UN peacekeeping force in Rwanda, Major General Romeo Dallaire, began using the term 'genocide' to describe the unfolding events in Rwanda $^{18}$. The use of the term 'genocide' to describe these events in Rwanda prompted a conflagration of controversy at the UN. With the 1992 failure of Somalia in such recent memory, the Clinton administration had no interests in getting involved in another conflict in Africa. Developed against the backdrop of the Somalia conundrum, the dogmatic lynchpin for this US policy was the presidential decision directive 25 (PDD-25), which circumscribed the conditions under which the US would intervene. This directive required that US participation in any UN operation must "advance US interests", while limiting US participation in UN missions and US support for other states intending to carry out UN-sanctioned missions. $^{19}$

Thus, when it comes to the political manoeuvring involved in 'naming the crime', conventional thinking holds that the Clinton administration officials avoided using the term 'genocide'. This was premised on the trepidation that using the term would have obliged the US to take action in terms of the 1948 Genocide Convention. $^{20}$ It is evident that the US did not want to admit that something catastrophic was indeed happening, which would impose a moral, if not legal responsibility to intervene. Consequently, US officials did not publicly use the word 'genocide' until after it became apparent to observers that genocide had indeed taken place. $^{21}$

While the humanitarian case for intervention could almost not be stronger, international support was unenthusiastic. The notion that the French offer was driven by national interest implied that the Security Council only authorised the French intervention for lack of anything better. It is argued that ten of the Council's fifteen members voted for the intervention while Brazil, China, New Zealand, Nigeria and 
Pakistan abstained. The prevailing national interest explanation of the intervention is reinforced by two factors. First, French actions were short of humanitarian outlooks until the decision to intervene was taken in June 1994. The French government did not allow its paratroopers who were evacuating French citizens from Rwanda to stop the massacres. It supported the initial withdrawal of the UN peacekeeping force, and eventually failed to offer logistical and financial support to an African peacekeeping force that was approved by the Security Council on 8 June. ${ }^{22}$

Second, it is apparent that France traditionally regarded Francophone Africa as an area of strategic interests. Close contact has been maintained by France with its fifteen former colonies, and eighteen military interventions have been undertaken in support of Francophone governments since 1962. Therefore, the intervention in Rwanda was broadly viewed as an attempt to circumvent the overthrow of the Francophone Hutu government by the Anglophone Rwanda Patriotic Front (RPF), with the view that inaction might diminish French standing in Africa. ${ }^{23}$

Though not officially, the PDD 25 was used as an informal guide for US policy towards Rwanda and it was augmented by a general sense of indifference regarding intervention. In response to requests by the African Affairs Bureau in the Pentagon to consider Rwanda a potential trouble spot, high-level administration officials were reported to have responded, "Take [Rwanda] off the list ... US national interest is not involved ... just make it go away." 24

The UN Security Council began in April 1994 to mull over the question of whether genocide was actually taking place after the emasculation of UNAMIR, with death tolls reaching an estimated 200 000. Representatives from the Czech Republic and New Zealand publicly entertained the possibility of genocide, while the US took a leading stance in opposition to the use of this strong discourse. Attributed to this was the absence of an intervention force that was ready and willing to intervene in Rwanda to stop the killing despite the fact that the prospect of genocide had caused a moral upsurge of support for action among the advocacy community. Barnett suggests that the innuendo was that to make such a move would only expand the gap between the moral imperative and the lack of action. ${ }^{25}$

Three factors can be attributed to the consensus regarding the decision to reduce UNAMIR's presence and mandate. First, the office of the Secretariat, Boutros-Ghali's office and the Department of Peacekeeping Operations (DPKO) gave an impression of distance and aloofness from the emerging tragedy. This stance reinforced the aversion among member states in the Security Council to propose a greater role for UNAMIR. It is apparent that it was at this time when most of the representatives of member states contributing troops to UNAMIR were concerned about the whereabouts or safety of their troops. Arguably, though, 
Boutros-Ghali also displayed a sense of indecision to the point of paralysis, if not sheer complacency. ${ }^{26}$

The second reason for the consensus to reduce UNAMIR's role was that no country was prepared to contribute its troops for an expanded mandate. Subsequently, those in the Security Council - mainly non-permanent members who were arguing for an intervention force had little ammunition: the Secretariat, who would be responsible for carrying out the mandate, was silent, which was generally interpreted as censure. No troop-contributing countries were volunteering for an expanded mandate and soon after the death of its soldiers, Belgium, which represented the backbone of UNAMIR, withdrew instantly and no state offered replacements. $^{27}$

Finally, with UNAMIR's mandate to oversee the Arusha Accords concluded, with many countries averse to contributing troops into an increasingly chaotic environment, and with access to the airport difficult, the Security Council had to protect its peacekeepers and the UN's reputation. This, regrettably, was a position argued by the US with others who constantly argued that the Security Council had a duty to protect the lives of peacekeepers. This was premised on the fact that failure to do so would result in difficulty obtaining troops in future, further diminishing the UN's repute. ${ }^{28}$

When the Secretariat eventually made public its long-awaited plan, the Security Council met it with substantial vehemence. This was more so because it merely created an image of a UN that was poised for intervention than because the plan was geared to contribute to stopping the genocide. Simply put, this proposal was purely a symbolic and unrealistic gesture: it proposed the dispatch of 5000 troops to Kigali, acknowledged that these troops might not be located for months, if ever, and confessed that it had no idea what they would do once the troops had arrived. It is not surprising that the US rightly disapproved of the plan as little more than smoke and demanded that the Secretariat and others in the Security Council design a pragmatic proposal. The United States also circulated its own suggestions for protecting and providing relief to the rising number of refugees. Because the US demurred to this preliminary proposal, it was widely portrayed in the media as representing an impediment to military intervention by the $\mathrm{UN}^{29}$

The decision on France's proposed intervention was greeted with much scepticism. France had long-standing ties with the same Hutu military that was being accused of genocide and the Security Council was concerned that France would seek intervention under humanitarian pretext on behalf of its Hutu allies. Towards the end of 1994, UNAMIR returned to Kigali in their numbers, long after 
the RPF had captured the country, approximately 800000 people had died, and about 2 million had become refugees. ${ }^{30}$

The oft-cited pessimistic raison d'être that the international community have not responded to international humanitarian emergencies because of some moral deficiency recurred. Critics have argued that the failure of states to take action illustrates the failure of norms; that the norms supported by individuals are inconsistent with state interests. It is worth noting the existence of the Genocide Convention, as well as taking cognisance that such failure on the part of states is not necessarily inconsistent with a resilient convention. Any failure of the convention is the result of a "badly phrased, unclear convention", as Bauer notes, but it remains a convention all the same, with international support. ${ }^{31}$ Thus, the focus should be to transform this normative commitment into a pragmatic set of guidelines.

A significant correlation exists between the discourse of acting in the best interests of the international community, the bureaucratisation of peacekeeping and the production of indifference. The conventional outlook offered by scholars of international relations is that states pursue their security interests, and therefore no matter how aggrieved member states were by the genocide in Rwanda, these states were reluctant to commit money and manpower, because it was not in their interest. In part, this provides an answer, but it does not sufficiently capture the dynamics of the Security Council's debate over Rwanda, nor does it explain why the Security Council vacillated over its decision or why the UN's repute was part of the moral calculus. Thus, misplaced from the traditional approach, is an appreciation of how the decision not to halt the genocide came to be understood and defined as ethical and moral. ${ }^{32}$

While it is irrefutable that states define interests in terms of quantifiable tangibles such as wealth and power as well as intangibles such as security and influence, this ostensibly self-centred outlook was neither unanticipated, nor the reason for inaction during the Rwandan genocide. States are not moral actors responsible for the welfare of all global citizens. In fact, states are broadly believed to be rational actors that protect themselves from unwanted conflict for pragmatic self-centred motives. In simple terms, states are selfish beings in an anarchic world, as realists doggedly point out. ${ }^{33}$ Therefore, in this view, to argue that the US or any other state's inaction was immoral is to argue that it was irrational. Consequently, an argument can be put forth that states did not fail, nor did the international system; rather, the system is neither configured nor geared to deal with humanitarian world problems.

International record of intervention in Africa displays patterns of indifference, scepticism, impotence and manipulation by states. States will continue 
to determine which international security issues to respond to and the significant change to make is to decrease the role of the state in matters of intervention. The responsibility to protect as a norm is becoming well entrenched, implying the necessity for structural change. By eliminating from the centre of intervention discourse, financial motives, state interests and partisanship, a moral argument comes to define success by the values and conditions delineated.

\section{The case of Darfur, 2003 and beyond}

The contemporary crisis in Darfur started in February 2003, when two rebel groups emerged in Darfur to challenge the National Islamic Front (NIF) government. The Sudan Liberation Army (SLA) and the Justice and Equality Movement (JEM) claimed that the government of Sudan discriminated against Muslim African ethnic groups in Darfur, and methodically targeted these ethnic groups since the early 1990s. The government of Sudan dismissed the SLA and JEM as terrorists. The conflict centred on the three African ethnic groups: the Fur, Zaghawa and Massaleit groups, in opposition to nomadic Arab ethnic groups. Intermittent hostilities between the largely African-Muslim ethnic groups and the Arab inhabitants of Darfur can be traced back to the 1930s and most recently surfaced in the 1980s. Consecutive governments in Khartoum have long neglected the African ethnic groups in Darfur and have done very little to prevent or contain attacks by Arab militias against non-Arabs in Darfur. ${ }^{34}$

\section{International response to the crisis in Darfur}

The systematic atrocities of the counterinsurgency war in Sudan's western province of Darfur have coincided with the tenth anniversary of the Rwandan genocide. Arguably, this has led to perceptions about Darfur as a test case by which to measure the extent to which the international community has improved at responding to genocide and crimes against humanity in the past decade. Kofi Annan explicitly created the connection between international responsibility in respect of Rwanda and Darfur in his memorial address for the Rwandan genocide in Geneva, on 7 April 2004. Speaking of ethnic cleansing in Darfur, he said, "the international community cannot stand idle" in the face of such widespread human rights violations. $^{35}$

In this address, Annan unequivocally referred to the mounting humanitarian crisis in Darfur, calling on the international community to take action. ${ }^{36}$ At the time when Annan gave his speech, approximately 30000 people were already dead, and about a million had fled their homes with 200000 of those pushed into refugee 
camps in Chad. ${ }^{37}$ Fact-finding missions sent into Darfur and Chad by the UN and Human Rights Watch, provided further evidence of 'systematic' crimes, killings, rape, and forced displacement perpetrated predominantly by the Sudanese government and the Janjaweed militia. ${ }^{38}$

During the crisis, many have looked to the US and the European Union (EU) to undertake greater measures, either unilaterally or through the UN, to end the violence in Darfur. Other than providing some logistical support to the African Union Mission in Sudan (AMIS), the West has remained uninspiring. For several reasons, European inaction in Darfur is more complex to explicate than American inaction. First, the EU arguably has a larger interest in African security and stability. Belgium, England, France and Portugal are European countries that have maintained extensive historical ties with Africa, and boast enduring relationships with their former colonies. Trade agreements, aid packages and foreign investment link the EU with Africa, and European concerns with illegal immigration and internal security threats are also being incessantly associated with volatility in Africa. ${ }^{39}$ Second, distinct from the US, the EU does not have a tarnished image as a norm-carrier. Moreover, the EU is not facing the sort of military overstretch that the US is experiencing in Iraq (though the numbers have decreased significantly) and Afghanistan. Pentland argues that the EU's capability for military action in Africa is in fact growing as the EU develops and enhances its military mechanisms. ${ }^{40}$ Finally, European intervention in Africa is not unprecedented. Of late, the UK sent troops to Sierra Leone in 2000, and France deployed its military to Cote d'Ivoire in 2003. ${ }^{41}$

China's opposition to sanctions and intervention in Darfur, reflects a difficulty to the US and European action through the Security Council. Of the permanent members in the Security Council, the US has taken the most assertive stance against Sudan, but the threat of China's veto has made pushing for tougher resolutions even more complex. ${ }^{42}$ While realists might maintain that the Security Council deliberations over Darfur expound the triumph of state power and interests over norms, analytical eclecticism suggests a more complex relationship between norms, interests and power. Dissimilar to realism, constructivism does not presuppose state interests; to a certain extent, constructivists seek to explore how interests and identities are created. This sets aside norms, and not just material interests, to comprise a state's identity. ${ }^{43}$ It can be argued, from a realist perspective, that norms fall short of the necessary clout to triumph on international issues, but from a more constructivist point of view, the US can use material power to pursue specific norms within the Security Council. Therefore, China's material power did not trump normative considerations categorically; to some extent, the US, Britain and France failed to push for stringent measures against Sudan's contravention of international human rights norms. 
Certainly, the 2004 Naivasha peace process was aimed at ending Sudan's civil war between Khartoum and the Sudanese People's Liberation Movement/Army (SPLM/A). It is argued that the agreement was still very delicate and the trepidation of endangering the cessation of Africa's longest civil war contributed to virtual lethargy in terms of international intervention. It was further argued that intervention would derail the essential co-operation between the SPLM/A and the government by buoying up both the SPLM/A and the rebels in Darfur, further protracting the civil war. ${ }^{44}$ Further complicating this was President Al-Bashir's trepidations of a potential movement for regime change if the Sudan Liberation Army (SLA), JEM and SPLM/A all made some inroads. Subsequently, some argued that exerting pressure on Khartoum over Darfur and Naivasha concurrently not only jeopardised a protracted civil war, but also threatened the possibility of deposing President AlBashir; thus, unravelling the security structures in Sudan. ${ }^{45}$

It is evident that the apprehension of exacerbating the conflict in Sudan is a clear illustration of the utilitarian nature of decision-making employed by the international community, especially the West; thus, also evidence of states facing a moral dilemma. A combination of the risk associated with intervention and the perceived significance of ending Sudan's civil war in the South, downgraded Darfur to a less important issue altogether. ${ }^{46}$ Such a stance calls into question the upshot of non-interference achieved via utilitarian rationale. It is also perceptible that the violence in Darfur has incessantly spilled over into Chad, rendering the conflict irresolvable and further elevating the humanitarian cost of perpetual violence. Evidence suggest, that the Janjaweed have been attacking Darfurian refugees as well as Chadian citizens, and that the Janjaweed co-ordinated attacks with both the Sudanese military and the Chadian rebels. ${ }^{47}$ Debatable in these cases, is the manner in which states as well as institutions such as the Security Council that are geared to intervene chose not to do so, notwithstanding the preconditions that invoked intervention in Somalia, Rwanda and Darfur.

It is improbable that the Security Council would have objected had others used force to halt the 1994 Rwandan genocide. ${ }^{48}$ Throughout the Security Council's deliberations about Rwanda no state publicly argued that either the ban on force (Article 2(4)) or the non-intervention rule (Article 2(7)) ought to prohibit armed action to halt the bloodshed. ${ }^{49}$ Moreover, as Chesterman has argued, little evidence suggests that sovereignty concerns inhibit states from saving strangers when they have the means and aspiration to do so. ${ }^{50}$ Throughout the $1990 \mathrm{~s}$, the Security Council expanded its interpretation of 'international peace and security', authorising interventions to protect civilians in so-called safe areas in Bosnia, maintain law and order, protect aid supplies in Somalia, and restore an elected government toppled by a coup in Haiti. Slim has argued that the central question of international 
responsibility for stopping intrastate violence remained essential, but unanswered in moral terms, legally, practically and institutionally. ${ }^{51}$

Short of intervention from the Security Council or the West, the AU was the only foreign force in Darfur. ${ }^{52}$ In August 2004, the AU deployed its first 300 of an envisaged 3000 troops to protect its civilian observers monitoring the oft-broken ceasefire agreement between the rebels and Sudanese government. ${ }^{53}$ Khartoum's repugnance for foreign intervention and the aversion and inability of the AU's Peace and Security Council to violate Sudanese sovereignty led to a provisional AU mandate in Darfur. ${ }^{54}$

\section{The African Union intervention in Darfur}

The end of the Cold War saw an upsurge in internal armed conflicts in many parts of the African continent. Following the decision to establish the AU, the constitutive legal text of the Union was drafted by the OAU Secretariat, and the AU entered into force in 2001. The AU Act is the first international treaty to recognise the right to intervene for humanitarian purposes - often referred to as 'humanitarian intervention'. The Act provides in Article 4(h) that the AU has the right to intervene in a member state, pursuant to a decision of the Assembly in respect of 'grave circumstances', namely war crimes, genocide and crimes against humanity. ${ }^{55}$ The recognition of the right to intervene in the AU Act has been hailed as reflective of the compassion of the new African intergovernmental organisation to contemporary demands and aspirations of ordinary Africans. However, the recent amendments of the AU Act introduced a new ground of intervention cognisance of the rights of the AU to intervene upon the recommendation of the Peace and Security Council. In this view, intervention will occur when there is a threat to legitimate order, as well as for the purpose of restoring peace and stability in a member state of the AU. It is unclear whether the intervention in Darfur was prompted by these pronouncements, despite the AU being at the forefront of this intervention. Perhaps the AU saw a testing ground for their stance on non-indifference, as well as demonstrating their African commitment.

The AU has advocated formal mechanisms with comprehensive peace and security responsibilities unparalleled in Asia, South America or the Middle East. Within Africa, leaders offer many reasons for this focus. Some view peace operations as the equivalent of putting out a fire in a neighbour's house, a moral impulse as well as a realistic understanding that, if left unchecked, the flames could spread throughout the neighbourhood. Other African leaders cite a responsibility to prevent future genocides on the continent, a call echoed by "no more Rwandas" - or cast it as "a matter of survival" for Africa. ${ }^{56}$ The AU operationalised its Peace and 
Security Council in 2003, as outlined by its Protocol, adopted in $2002 .{ }^{57}$ Soon after, the African Union launched its first peacekeeping operation in Burundi. The AU deployed its second operation, a ceasefire monitoring force in Darfur, in June 2004. The ambitious AU agenda also includes development of sub-regional brigades to comprise its proposed African Standby Force (ASF) by 2010. It is unclear whether the intervention in Darfur was prompted by these pronouncements and the subsequent ASF, despite the AU being at the forefront of this intervention. It should be mentioned that the African Mission in Somalia (AMISOM), African Mission in Sudan (AMIS) and the AU intervention in the Comoros later, were AU-driven initiatives. By the time of writing this article, the ASF was not yet operational and ready to undertake interventionist missions.

The AU has done as much as could be expected with its limited resources and mandate, but its limitations are now being exposed. It is argued that when the degree of the catastrophe became impossible to overlook, by mid-2004, the AU established a small monitoring mission in Darfur, consisting of some sixty monitors with 300 troops to protect them. Over the next couple of years, the mission has steadily expanded to some 7000 troops. Nonetheless, there has been a mismatch between objectives and capabilities. A significant drawback of the AU mission was its mandate as principally an observer mission without a mandate to proactively protect civilians. The mission could only protect civilians where they were being attacked in its presence, and then only if enough troops were available to intervene. Too often this has failed. ${ }^{58}$

There are two fundamental ideas and norms entrenched within the AU's collective security identity that elucidate why it became involved in Darfur. The connections between the AU's identity and empirical realities in Sudan have shaped the role of AMIS. The first central idea constituting the AU's collective security identity reflects the notion of a pan-African security regime. The AU's predecessor, the Organisation of African Unity (OAU), attempted to develop a collective security framework for the continent, but an effective pan-African security apparatus never fully emerged. ${ }^{59}$ To remedy the ineffectiveness of the OAU's security mechanisms, the AU created and institutionalised the Peace and Security Council (PSC) in December 2003. Pan-African in scope, the PSC is designed to "promote peace, security and stability in Africa... implement peace-building and post-conflict reconstruction ... protect human rights ... [and] develop a common defence policy for the Union". 60

The second idea comprising the AU's collective security identity is a strong institutionalisation of the norms of humanitarian intervention. While the AU's Constitutive Act affirms the primacy of state sovereignty, it also provides for a 
strong protection mandate in the case of genocide, war crimes and crimes against humanity (Article 4(h)). In addition, distinct from the OAU, the AU does not require the consent of the state whose sovereignty is being violated, to proceed with an intervention. $^{61}$ Thus, the $\mathrm{AU}$ has taken the institutional steps necessary to operationalise a pan-African security regime, even when it required the violation of sovereignty.

These foundational ideas and norms underline the AU's motivation to intervene in Darfur. The AU aims to provide pan-African security and it has formalised a strong protection mandate within its Constitutive Act. Darfur is arguably the largest contemporary humanitarian crisis in Africa. ${ }^{62}$ Thus, if the AU remained on the periphery then the goals and foundational ideas of the AU would be rendered ineffectual and insignificant. It is conflicts such as Darfur that the AU's security mechanisms are designed to prevent or resolve. Notwithstanding these robust foundational ideas, the AU has accepted a very limited protection mandate in Darfur and has proceeded only with the consent of Khartoum. This is, in part, due to the empirical realities in Sudan and the AU, coupled with the fears about splitting the organisation into Arab and African schisms. Khartoum is averse to give the AU greater scope in Darfur, and the AU has neither the political capacity to force the Sudanese government to acquiesce to a stronger mandate, nor the military capacity to intervene without consent. As it stands, the AU is incapable of adequately carrying out the limited mandate it does have, let alone acting as an intervention force.

The AU has demonstrated leadership, but it seems as if only the UN can guarantee a synchronised, resourced and justifiable international response to a conflict of this enormity. The UN, an architecture of its member states, has been found wanting in Darfur. It has been inexcusably sluggish in applying pressure on the Sudanese government. It was only in March 2005, some two years after the conflict started, and in the face of repeated provocations from the Sudanese government - including its utter failure to disarm the Janjaweed - that the Security Council belatedly moved to impose sanctions against those hindering the peace process and committing human rights violations. ${ }^{63}$

Somalia, Rwanda and Darfur are clear cases depicting interventions gone wrong or the reluctance to intervene by those geared to, as well as those who are willing but incapable. There have been other instances in Africa where pronouncements to intervene were marked by positive results of those interventions, and Sierra Leone in 2000 and the Comoros in 2008 are cases in point. This section seeks to demarcate briefly the pessimism following some interventions in Africa and the subsequent optimism that followed other interventions. It is in these subsequent 
cases where the absence of controversy as well as the dearth in literature on these interventions led to a rather shortened exposition of the two cases.

\section{British intervention in Sierra Leone, 2000}

The Lomé peace agreement of 1999 sought an end to the civil war in Sierra Leone via a number of restricted political compromises to the Revolutionary United Front (RUF). UN Security Council Resolution 1289 noted the withdrawal of the Economic Community of West African States Monitoring Group (ECOMOG) force, with its meaningful contribution towards the restoration of democracy and the maintenance of peace, security and stability, and reinforced the UN Mission in Sierra Leone (UNAMSIL). At the beginning of May 2000, RUF rebels reneged on the agreement by returning to arms, attacking UN forces and detaining about 500 people. The United Kingdom decided to intervene, seeking to achieve a set of goals: to protect and evacuate almost 500 British nationals, to secure the use of Freetown airport, to provide technical advice to UNAMSIL, and to help stabilise the situation in Sierra Leone. ${ }^{64}$

The British government's 'ethical diplomacy' ended the violence in Sierra Leone against a population that had been subjected to a particularly brutal war since 1991. The 650 paratroopers who landed in May 2000 to support pro-government forces and the $11000 \mathrm{UN}$ blue helmets carried the war to the rebels of the RUF, forcing them to sign and abide by a final peace agreement. Nonetheless, peace had been imposed at a heavy price: willingness to overlook the war crimes committed by pro-government forces, an embargo on aid to RUF zones and the transfer of the most intransigent combatants to Liberia, where some of them were encouraged to overthrow Charles Taylor. ${ }^{65}$

The decision to deploy British troops in the largest unilateral military intervention since the Falklands war was taken amid some confusion. Arguably, the Sierra Leonean crisis came when Prime Minister Blair was preoccupied with the situation in Northern Ireland and the Irish Republican Army's statement on decommissioning. It is argued that the main catalyst stemmed from a panic-stricken report from the UN, claiming that Freetown was poised to fall to the rebels. Nonetheless, it appears as if British military intervention in Sierra Leone was not a foregone conclusion. It is argued that British presence in major operations outside Europe remained less likely, in part because of its strategy to enhance peacekeeping capacity of African governments, and partly because peacekeeping would most likely assume a profile of infrastructural support for other nations, specifically in Africa. ${ }^{66}$ 
The extent to which the media played a role in the events preceding the British intervention in Sierra Leone remains a mystery. Theirs was an intervention driven by the interests of British citizens, as well as a faltering UN mission. Even though what unfolded in Sierra Leone invoked humanitarian concerns by those geared to intervene, these events did not inspire extensive media coverage and the media'ssubsequent effect in shaping matters of intervention. This intervention was shrouded in secrecy, especially during its planning phase and towards the execution. The role of the media in this case was ex post facto, largely focusing on the successful nature of the intervention, rather than the humanitarian concerns. Another inspiring tale of a successful military intervention was staged by the $\mathrm{AU}$ in the Comoros in 2007, as will be put forth in the next section.

\section{The AU intervention in the Comoros, 2007}

In an exchange of gunfire, national government troops stationed in Anjouan, one of the three semi-autonomous islands that make up the Comoros, clashed with police in May 2007. Following elections for each island, which were scheduled for June 2007, the archipelago's delicate power-sharing agreement hung in the balance. In the development that ensued, the AU pronounced its intention to send troops to the Comoros. ${ }^{67}$ The AU was reported to have sent troops to the Comoros following secessionist tendencies displayed by Anjouan's out-going leader, Mohamed Bacar. Bacar refused to step down as the constitution demanded, if he intended to run for president again. ${ }^{68}$

After a series of negotiations and the AU attempts to resolve the political impasse between the Union of Comoros and one of its semi-autonomous islands, sanctions against Anjouan's 'authorities' were imposed. It was also indicated that, in the event of Bacar's unremitting non-compliance with the AU and the Union government, stringent measures including air and sea blockades would be implemented as well as the AU Electoral and Security Mission to the Comoros (MAES). ${ }^{69}$

Military action to restore the authority of the Union government was approved, subsequent to a meeting, held under the auspices of the AU's PSC, by the Ministers of Foreign Affairs of Tanzania, Libya, Sudan and Senegal in Addis Ababa on 20 February $2008 .{ }^{70}$ Despite South Africa's opposition to the use of force, the AU forces and troops from the Indian Ocean archipelago of the Comoros seized the rebel island of Anjouan on March 2008. More than 1300 troops attacked at dawn to topple Bacar, a French-trained former gendarme who had taken power in 2001 and had clung on after an illegal election in 2007. Tanzania and Sudan spearheaded the $\mathrm{AU}$ mission in the Comoros, and these were the two states facing calls for 
independence from semi-autonomous Zanzibar and southern Sudan respectively. Conversely, South Africa, after failed attempts at mediating the crisis, criticised the AU's military assault. Then President, Thabo Mbeki was quoted as saying that it is unfortunate that the military action had taken place, because it had taken the Comoros back to the history of the use of force, instead of resolving matters in a peaceful manner. ${ }^{71}$

The media did not extensively cover the events leading to the AU intervention in the Comoros. It can be argued that what unfolded in the Comoros perhaps lacked humanitarian overtones to justify concerns by the international community to consider intervention. The nature of the crisis was such that it did not create an atmosphere of empathy within the international community, despite the condemnation it received from the $\mathrm{AU}$ and its subsequent intervention. The successful nature of the interventions in Sierra Leone and the Comoros indicated that not much was newsworthy, simply because the interventions were short and successful. As a result, the length of media coverage in these two cases is rather limited as compared to the extensive nature of events in Somalia and Darfur.

\section{Conclusion}

The article explained the extent to which military intervention in Africa has evolved since the end of the Cold War, in terms of theory, practice and how it unfolded upon the African continent. This was achieved by focusing on both successful and unsuccessful cases of military intervention in Africa. The unsuccessful cases include Somalia (1992), Rwanda (1994), and Darfur (2003) on the one hand and the successful cases being Sierra Leone (2000) and the Comoros (2008) on the other. The intervention in Somalia provided a litmus test for postCold War interventions and the departure point for their ensuing evolution. Of interest here, is the prevalent optimism that existed prior to the intervention and the subsequent pessimism after the departure of US forces. The Rwandan crisis, however, came immediately after Somalia, explaining how the reluctance to intervene featured during this episode. The case of Darfur marked the willingness of the AU to intervene, in contrast with the ensuing debates at the Security Council over naming the crime whether or not genocide was unfolding in Darfur. In a more positive light, the intervention by Britain in Sierra Leone and the AU intervention in the Comoros are clear illustrations of how such intervening was articulate in what the interveners intended to do and their subsequent success. While the interests motivating Western states to intervene seem to have metamorphosed fundamentally with the end of the Cold War, the demand for military intervention in Africa immensely exceeds the supply. 
Significant to this article, military intervention has always had a more conspicuously dissimilar standing than that of other forms of intervention. Nevertheless, the upsurge in non-military intervention has transformed the milieu in which military intervention occurs. Equally, the non-intervention rule always stood on a delicate ethical underpinning. The moral calculus behind the rule involves a clear consequential choice to give priority to order over justice in international relations. Thus, in an era of fundamental transformation in world politics, both theory and practice in international relations are moving toward a re-examination of the costs and benefits of the non-intervention rule. The sources of intervention in the 1990s are found in these changes in world politics.

Conclusions can be drawn that the US decision to deploy ground troops in Somalia was a utilitarian case to study. The intervention marks conceivably the most outstanding illustration of forcible intervention during humanitarian crisis. Establishing the origin of the intervention in this case is therefore of significant interest to those in humanitarian and foreign policy circles, who seek to explain what triggers intervention. This justification underpins other major studies that have focused on Somalia.

The number of humanitarian-driven enforcement operations is reduced by the disinclination among the Western powers to intervene, unless it can be done quickly with a minimum of risk. Few contemporary conflicts can be found in this category. The dearth in zest for humanitarian intervention amongst the Western powers and the international community at large was underlined by the genocide in Rwanda. Not one of the nineteen governments, which, at that time, had undertaken to have troops on standby for UN service wanted to contribute troops to a UN operation in Rwanda and almost one million people had to be massacred before France felt pressed to act.

\section{Endnotes}

${ }^{1}$ Von Hippel, K. "The non-interventionary norm prevails: An analysis of western Sahara". The Journal of Modern African Studies 33/1. 1995. 68.

2 Jakobsen, PV. "National interests, humanitarian or CNN: What triggers UN peace enforcement after the Cold War". Journal of Peace Research 33/2. 1996. 205.

${ }^{3}$ Livingston, S \& Eachus, T. "Humanitarian crises and US foreign policy". Political Communication 12. 1995. 419-426.

${ }^{4}$ Talentino, AK. Military intervention after the Cold War: The evolution of theory and practice. Athens: Ohio University Press, 2005, 106. 
${ }^{5}$ Cusimano, MK. Operation Restore Hope: The Bush Administration's decision to intervene in Somalia. Pew Case Studies in International Affairs. Washington, DC: Institute for the Study of Diplomacy, 1995, 10.

${ }^{6}$ Robinson, P. "Operation Restore Hope and the illusion of a news media driven intervention”. Political Studies 49. 2001. 946.

${ }^{7}$ Hirsch, JL \& Oakley, RB. Somalia and Operation Restore Hope: Reflections on peacemaking and peacekeeping. Washington, DC: United States Institute of Peace Press, 1995, 73.

${ }^{8}$ Bolton, JR. "Wrong turn in Somalia". Foreign Affairs 73/1. 1994. 56.

${ }^{9}$ Ibid, p. 57.

${ }^{10}$ Ibid.

11 Talentino, op. cit. p. 109.

12 Ibid, p. 110.

${ }^{13}$ Ibid, p. 114.

${ }^{14}$ Ibid, p. 115.

${ }^{15}$ Ibid, pp. 116-117.

${ }^{16}$ Jakobsen, op. cit. p. 209.

${ }^{17}$ Kuperman, AJ. The limits of humanitarian intervention: Genocide in Rwanda. Washington, DC: Brookings Institution of Peace, 2001.

${ }^{18}$ Dallaire, R. Shake hands with the devil: The failure of humanity in Rwanda. New York: Carroll \& Graf, 2005, 333.

${ }^{19}$ PDD 25. "Clinton Administration policy on reforming multilateral peacekeeping operations." Presidential Decision Directive 25. 3 May 1994. <http://www.fas.org/irp/offdocs/pdd25.htm> Accessed on 5 April 2009.

${ }^{20}$ Rieff, D. At the point of a gun: Democratic dreams and armed intervention. New York: Simon \& Schuster, 2005, 74-75.

${ }^{21}$ Power, S. A problem from hell: America and the age of genocide. New York: Perennial, 2002, 362.

22 Jakobsen, op. cit.

${ }^{23}$ Dowden, R. "A very French affair in Rwanda: Mitterrand's military adventure is rooted in imperial tradition". The Independent. 6 July 1994, 3 ..

${ }^{24}$ Power, op. cit. p. 342.

${ }^{25}$ Barnett, MN. Eyewitness to genocide: The UN and Rwanda. Ithaca, NY: Cornell University Press, 2002, 131.

${ }^{26}$ Barnett, MN. "The UN Security Council, indifference, and genocide in Rwanda". Cultural Anthropology 12/4. 1997. 558.

${ }^{27}$ Ibid, p. 559.

28 Ibid.

${ }^{29}$ Ibid, p. 560.

${ }^{30} \mathrm{Ibid}$, p. 561

${ }^{31}$ Bauer, Y. "Comparisons of genocides". In Chorbajian, L \& Shirinion, J (eds), Studies in comparative genocide, New York: St Martin's Press, 1999.

${ }^{32}$ Barnett, "The UN Security Council ...", op. cit. p. 562.

33 Staub, E. "Preventing genocide: Activating bystanders, helping victims heal, helping groups overcome hostility". In Chorbajian, L \& Shirinion, J (eds), 
Studies in comparative genocide, New York: St Martin's Press, 1999, 251254.

${ }^{34}$ Williams, PD \& Bellamy, AJ. "The responsibility to protect and the crisis in Darfur”. Security Dialogue 36/1. 2005. 30.

${ }^{35}$ Annan, K. Address to the UN Commission on Human Rights. UN News Service. 7 April 2004. <http://www.un.org/apps/news/printnewsAr.asp?nid=10377> Accessed on 5 April 2009.

36 Clough, M. "Darfur: Whose responsibility to protect?" Human Rights Watch. March 2005. <http://hrw.org/wr2k5/darfur/darfur.pdf> Accessed on 5 April 2009.

${ }^{37}$ Williams \& Bellamy, op. cit. p. 30.

38 Slim, H. "Dithering over Darfur? A preliminary review of the international response". International Affairs 80/5. 2005. 814.

39 Pentland, CC. "The European Union and the civil conflict in Africa". International Journal 60/4. 2005. 923-924.

${ }^{40}$ Ibid, p. 924.

${ }^{41}$ Ibid, pp. 931-932.

${ }^{42}$ Bellamy, AJ. "Responsibility to protect or Trojan horse? The crisis in Darfur and humanitarian intervention after Iraq". Ethics \& International Affairs 19/2. 2006. 46.

${ }^{43}$ Farrell, T. "Constructivist security studies: Portrait of a research program". The International Studies Review 4/1. 2002. 50.

${ }^{44}$ Williams \& Bellamy, op. cit. p. 39.

${ }^{45}$ Slim, op. cit. p. 822.

${ }^{46}$ Williams \& Bellamy, op. cit. p. 38.

47 Human Rights Watch. "Darfur bleeds: Recent cross-border violence in Chad". Human Rights Watch Backgrounder. February 2006. <http://www.hrw.org/backgrounder/africa/chad0206/chad0206.pdf> Accessed on 23 April 2009.

48 Wheeler, NJ. Saving strangers: Humanitarian intervention in international society. Oxford: Oxford University Press, 2001, 232.

${ }^{49}$ Barnett, Eyewitness to genocide ..., op. cit.

50 Chesterman, S. Just war or just peace: Humanitarian intervention and international law. Oxford: Oxford University Press, 2001, 231.

${ }^{51}$ Slim, op. cit. p. 820.

52 O'Neill, WG \& Cassis, V. Protecting two million internally displaced: The success and shortcomings of the African Union in Darfur. University of Bern Project on Internal Displacement, 2005, 16.

53 Ibid.

${ }^{54}$ Ibid, p. 26.

55 African Union. Constitutive Act of the African Union. Article 4, 2000.

${ }^{56}$ Holt, VK \& Shanahan, MK. African capacity-building for peace operations: UN collaboration with the African Union and ECOWAS. Washington, DC: The Henry L Stimson Center, 2005, 8. 
${ }^{57}$ African Union. Protocol relating to the establishment of the Peace and Security Council of the African Union, 2003.

${ }^{58}$ Grono, N. Darfur: "The international community's failure to protect". African Affairs 105/421. 2006. 625-626.

59 Powell, K \& Tieku, TK. "The African Union's new security agenda". International Journal 60/4. 2005. 941.

${ }^{60}$ African Union. "Protocol relating to the establishment of the Peace and Security Council of the AU". African Union Treaties, Conventions, Protocols, Charters. <http://www.africa-union.org/root/au/Documents/Treaties/Text/ Protocol_peace\%20and\%20security.pdf> Accessed on 26 April 2009.

${ }^{61}$ Powell \& Tieku, op. cit. pp. 947-948.

${ }^{62}$ Clough, op. cit.

${ }^{63}$ Grono, op. cit. p. 626.

${ }^{64}$ Ortega, M. Military intervention and the European Union. Chaillot Paper 45, Institute for Security Studies of Western European Union, 2001, 36.

${ }^{65}$ Weissman, F. "Sierra Leone, peace at any price". In Weissman, F (ed), In the shadow of just wars: Violence, politics and humanitarian action, London: Cornell University Press, 2004.

${ }^{66}$ William, P. "Fighting for Freetown: British military intervention in Sierra Leone". In McInnes, C \& Wheeler, NJ (eds), Dimensions of Western military intervention, Oxford: Routledge, 2002, 154-156.

67 "Comoros: Violent electoral run-up". Africa Research Bulletin 44/5. 2007. 17076.

68 "Comoros: AU troop mission". Africa Research Bulletin 44/5. 2007. 17085.

69 "Comoros: Sanctions applied". Africa Research Bulletin 44/10. 2007. 1727317274.

70 "Comoros Islands: Military action approved". Africa Research Bulletin 45/2. 2008. 17428.

71 "Comoros Islands: AU troops invade Anjouan". Africa Research Bulletin 45/3. 2008. 17463-17464. 